\title{
REPORT OF THE CHAIRMAN OF THE COMMITTEE ON REVISION OF THE CONSTITUTION AND BY-LAWS.
}

[Miss ANNIE W. Goonsich presented the report of the Committee on the Revision of the Constitution and By-laws, a copy of which will be mailed to each member in due time and the suggested changes will be fully discussed at the next meeting before adoption. This is a subject to which every member should give careful consideration.-ED.]

ARticle I.-Name.

(Amend by striking out "American Society of Superintendents of Training-Schools" to read as follows:)

"This organization shall be known as the American Nurses' Educational Association."

Article II.-OBJect.

(Complete revision to read as follows:)

"The object of this association shall be to consider all questions relating to nursing education; to define and maintain in schools of nursing throughout the country minimum standards for admission and graduation; to assist in furthering all matters pertaining to public health; to aid in all measures for public good by coöperation with other educational bodies, philanthropic and social; to promote by meetings, papers, and discussions cordial professional relations and fellowship; and in all ways to develop and maintain the highest ideals in the nursing profession."

ARTICLE III.-MEMrers.

(Amend by inserting "Associate" to read as follows:)

"There shall be three classes of members:

"(1) Active.

"(2) Associate.

"(3) Honorary."

Article IV.-Classes of Members.

(Revision of first photograph to include active and associate members, to read as follows:)

"Active members of the association shall include members of the preliminary organization, all past superintendents who were members while holding that position, all present superintendents of schools of nursing, superintendents of hospitals, superintendents of special educational departments of nursing, and associate members if qualified as specified in the by-laws and acceptable to the association. 
"Associate members shall include all school instructors and heads of special departments of nursing work, if qualified as specified in the by-laws and acceptable to the association. They shall be eligible for such membership during the time they are holding such appointments.

" Honorary members shall be those of whom the association wishes to signify its appreciation and hold in grateful remembrance for signal service to the profession or to humanity."

\section{BY-LAWS.}

Artiole II.-Membership Qualifications.

(Paragraphs 1, 2, and 3 completely revised.)

"Active members shall be graduates of training-schools connected with general hospitals giving not less than a two-years' course of training in the wards of the hospital, or whose experience gained by postgraduate or other additional school work might justly be considered its equivalent. They must be endorsed by two members.

"Associate members who have held office for not less than thrce consecutive years and been members of the association for the same length of time may become active membcrs by the unanimous vote of the members present at any regular meeting, thcir names having been duly considered by the council and proposed in writing by three active members. Associate members shall have the same qualifications and endorsements as active members, and shall be entilled to the same privileges in vote and debate."

(Paragraph 4 amended to include candidates for associate membership.)

"Every candidate for admission to membership, both active and associate, shall make application to the president for a blank form which she shall fill out and return, to be sent by the president to the council for consideration. Final action by the council shall be taken at the council meeting immediately previous to the annual meeting, and the names of all candidates with recommendation of the council thereon shall be presented to the association for action at the annual meeting."

(Paragraph 6 amended to read as follows:)

"Proposals for honorary membership shall be signed by three active members and shall be presented at an annual meeting. The election shall be unanimous."

\section{Article III.-Fees and Assessments.}

(Amended to read as follows:)

"The initiation fees for both active and associate members shall be two dollars and the annual dues three dollars, payable on January 1 of 
each year. Any member who shall fail to pay her annual dues by April 1 shall receive special notice from the treasurer, and if the dues are not paid within three months from that date she shall be regarded as having resigned her membership unless such dues shall have been remitted by the council for good and sufficient reasons.

\section{ARTICLE IV.-WithDRAWAL.}

(Amended by striking out paragraph 2, this having been embodied in the previous article.)

\section{Article V.-Election of Officers.}

(Amended to read as follows:)

"A Nominating Committee of three shall be appointed by the president before the close of the first session of the annual meeting. This committee shall select at least two names for each office to be filled and shall present them to the association at the first session on the following day, the election to take place before the close of the last session.

"The person who shall receive a two-thirds vote shall be declared to be elected to the office for which she has been nominated."

\section{ARTicle VI.}

(Amended by striking out paragraph 1 and inserting "president" at the beginning of paragraph 2, to read as follows:)

"The president, secretary, and treasurer are eligible for reëlection."

(And the insertion of the following paragraph:)

"Two councillors shall be elected for three years and one auditor for two years."

(Paragraph 3 amended by striking out " and councillors," to read:)

"All officers shall enter upon their duties upon the ending of the present convention. When any vacancies occur in any of the offices of the society they shall be filled by the council until the next annual meeting."

ARTICle VIII.-Duties OF OFficers.

(Amended by striking out last three paragraphs concerning the duties of the council.)

\section{Article IX.-Counoil.}

(The duties of the council to read as follows:)

"The council is empowered to manage all the affairs of the association, subject to the constitution and by-laws; to appoint committees from the membership of the association, and spend money out of its 
surplus funds for special investigations in matters pertaining to the objects of the association, and to publish reports of such investigations. The council may also engage in the regular publication of reports, papers, transactions, and other matters in an annual volume, or in such manner and at such time as it may determine, with the approval of the association.

"The council shall keep a careful record of its proceedings and make an annual report. All arrangements for the annual meetings shall be made by the council; it shall also determine the order of business for each annual meeting and have the same printed for the use of the members during the sessions."

\section{ARTICLE X.}

(Former Article IX. unchanged.)

\section{REPORT OF THE SECRETARY OF THE AMERICAN SOCIETY OF SUPERINTENDENTS OF TRAINING. SCHOOLS FOR NURSES}

THE eleventh annual convention of the American Society of Superintendents of Training-Schools for Nurses was held at Washington, D. C., May 1, 2, and 3. Following the plan, which had proved so satisfactory at Pittsburg, of holding the meetings of the convention in the hotel serving as headquarters for members of the society, the Shoreham Hotel was selected for this purpose, and the meetings were held in its Assembly-Room. In response to a desire expressed by many members of the society, evening sessions were arranged for in order that the afternoons might be left free for visiting the many places of interest in Washington, which can only be seen to advantage in the daytime. The attendance at all sessions of the convention was unusually large. The papers were of a very high order of excellence, the discussions spirited and interesting.

The first session was called to order on Monday, May 1, at ten A.M., the president, Miss Georgia M. Nevins, in the chair. The invocation by the Rev. U. G. B. Pierce, of All Souls' Church, was followed by an address of welcome from President Needham, of the George Washington University. Dr. Needham spoke of nursing as one of the oldest of the professions. He showed how it had been affected by the advance in medicine, and how in turn medicine was affected by the improvements in nursing. He called attention to the growing tendency to return to 